\title{
THE EFFECT OF MANAGEMENT CHANGE, AUDIT OPINION, COMPANY SIZE, FINANCIAL DISTRESS AND AUDITOR REPUTATION ON AUDITOR SWITCHING
}

\begin{tabular}{|c|c|}
\hline \multicolumn{2}{|c|}{$\begin{array}{c}\text { Ahmad Zakie Mubarrok', Almer Reyhan Islam² } \\
{ }^{1} \text { Universitas Padjadjaran, Bandung, Indonesia, Email: ahmad.zakie@unpad.ac.id } \\
2 \text { Universitas Widyatama, Bandung, Indonesia, Email: almerreyhanislam@gmail.com }\end{array}$} \\
\hline INFO ARTIKEL & ABSTRAK/ABSTRACT \\
\hline $\begin{array}{l}\text { Histori Artikel : } \\
\text { Tgl. Masuk : } 07 \text { September } 2020 \\
\text { Tgl. Diterima : } 29 \text { September } 2020 \\
\text { Tersedia Online : } 29 \text { September } 2020 \\
\text { Keywords: } \\
\text { Management Change, Audit Opinion, } \\
\text { Company Size, Financial Distress, } \\
\text { Auditor Reputation, Auditor Switching. }\end{array}$ & $\begin{array}{l}\text { This study aims to empirically prove the effect of } \\
\text { management change, audit opinion, company size, financial } \\
\text { distress and auditor reputation on auditor switching. This } \\
\text { research was conducted on manufacturing companies that } \\
\text { have been listed in Indonesian Stock Exchange from } 2016 \\
-2018 . \text { There were } 109 \text { companies collected for } \\
\text { observation in which they were taken by the method of } \\
\text { purposive sampling. An analytical technique employed is } \\
\text { logistic regression analysis. The results of hypothesis } \\
\text { testing in this research indicate that management change, } \\
\text { audit opinion, financial distress and auditor reputation } \\
\text { affects the auditor switching. Meanwhile variabel of } \\
\text { company size affect auditor switching, but in positive effect. }\end{array}$ \\
\hline
\end{tabular}

\section{PENDAHULUAN}

Laporan keuangan merupakan bentuk pertanggungjawaban dan penyampaian informasi keuangan suatu perusahaan atau organisasi kepada pihak - pihak yang membutuhkan, baik pihak eksternal maupun internal (Jensen dan Meckling, 1976). Disinilah pentingnya sistem pelaporan akuntansi dan auditing dalam proses pemenuhan kontrak sosial perusahaan dengan para stakeholders. Untuk meyakinkan bahwa laporan keuangan perusahaan tersebut memiliki kredibilitas yang berguna bagi user, maka laporan keuangan tersebut harus diaudit oleh auditor independen. Auditor independen yang dimaksud adalah Kantor Akuntan Publik (KAP).

Auditor yang memiliki kredibilitas, selain bertanggungjawab untuk mendeteksi adanya penyajian kesalahan yang material, juga memberikan rekomendasi kepada klien dalam berbagai hal seperti perbaikan pengendalian internal maupun yang terkait dengan kelangsungan usaha perusahaan. Auditor diwajibikan untuk mematuhi Kode Etik Profesi Akuntan Publik yang mencakup Prinsip Dasar Etika termasuk di dalamnya adalah bersikap profesional.

Manajemen memerlukan auditor yang berkualitas dan mampu memenuhi tuntutan pertumbuhan perusahaan yang cepat. Apabila hal ini tidak dapat dipenuhi, kemungkinan besar perusahaan akan mempertimbangkan untuk mengganti auditor yang ada saat ini. Dengan mengganti auditor lama dengan auditor yang dipandang lebih punya nama, maka reputasi perusahaan juga akan terangkat di kalangan investor (Kawijaya \& Juniarti, 2002).

Manajemen diberikan sebagian kekuasaan untuk membuat keputusan bagi kepentingan terbaik pemegang saham. Oleh karena itu, manajemen wajib mempertanggungjawabkan segala tindakannya kepada pemegang saham. Dalam hal ini pergantian auditor (auditor switching) seringkali dihubungkan dengan adanya adverse selection dan moral 
hazard di antara agent dan principle. Lebih lanjut, perusahaan sendiri atau manajemen cenderung menginginkan auditor memberikan opini wajar tanpa pengecualian (unqualified opinion) atas laporan keuangannya. Hal ini membuat jenis opini diluar itu tidak diinginkan oleh manajemen dan dipandang tidak begitu memberi manfaat bagi pengguna laporan keuangan (Willingham \& Charmichael, 1997).

$$
\mathrm{Di} \text { Indonesia, sebelumnya }
$$

pengaturan mengenai KAP diatur berdasarkan Peraturan Menteri Keuangan (PMK) No. 17/PMK.01/2008 tentang Jasa Akuntan Publik tanggal 5 Februari 2008. Berdasarkan pengaturan dalam PMK No.17 tersebut di atas, sebuah Kantor Akuntan Publik (KAP) hanya boleh mengaudit sebuah perusahaan paling lama 6 (enam) tahun buku berturut-turut, sedangkan bagi Akuntan Publik (AP) di dalam KAP tersebut hanya diperbolehkan mengaudit paling lama 3 (tiga) tahun buku berturut-turut.

Pada tanggal 6 April 2015, Pemerintah telah menerbitkan Peraturan Pemerintah (PP) No. 20 tahun 2015 tentang Praktik Akuntan Publik (PP 20/2015) yang merupakan pengaturan lebih lanjut dari Undang-undang No. 5 tahun 2011 tentang Akuntan Publik. Berdasarkan aturan ini, tidak ada pembatasan lagi untuk KAP. Adapun pembatasan hanya berlaku untuk AP yaitu selama 5 (lima) tahun buku berturut - turut. Hal ini tentunya akan menimbulkan suatu pertimbangan baru bagi manajemen dalam memutuskan untuk melakukan pergantian auditor atau tidak.

Penelitian - penelitian terdahulu mengenai pergantian auditor menyatakan bahwa terdapat beberapa faktor yang mempengaruhi pergantian auditor, diantaranya adanya perubahan manajemen, ketidaksepakatan antara klien dan auditor, ketidakpuasan atas audit fee ( Woo \& Koh, 2001, Ismail et al., 2008), leverage dan kesempatan untuk melakukan manipulasi income (Woo \& Koh, 2001), diterbitkannya opini wajar dengan pengecualian (Hudaib \& Cooke, 2005), financial distress (Naseer et al., 2006), pertumbuhan perusahaan (Woo \&
Koh, 2001; Nasser et al., 2006), risiko finansial perusahaan (Nasser et al., 2006) dan ukuran KAP (Carpenter \& Strawser, 1971). Faktor - faktor ini tidak selalu berlaku di semua negara, beberapa penelitian yang dilakukan di beberapa negara yang berbeda menunjukkan hasil yang berbeda pula.

Di Indonesia, Setyorini dan Ardiati (2006) meneliti fenomena pergantian auditor yang dihubungkan dengan kondisi financial distress, qualified opinion, perubahan manajemen, dan ukuran KAP. Hasil penelitian tersebut menunjukkan fakta potensi kebangkrutan perusahaan publik tidak mempengaruhi pergantian auditor. Penelitian terbaru mengenai topik ini juga dilakukan juga oleh Prahartari (2013) dan Alisa, Devi \& Brillyandra (2019) yang meneliti tentang fenomena pergantian auditor yang dihubungkan dengan kondisi pergantian manajemen, opini audit, ukuran perusahaan klien, financial distress dan ukuran auditor.

Berdasarkan hasil penelitian sebelumnya, maka tujuan penelitian ini adalah untuk melakukan uji ulang terhadap konsistensi hasil dengan penelitian sebelumnya pada periode dan kondisi pasar modal yang berbeda. Pada penelitian ini sampel yang digunakan adalah perusahaan manufaktur yang terdaftar pada Bursa Efek Indonesia (BEI) pada tahun $2016-2018$.

\section{KERANGKA TEORITIS DAN PENGEMBANGAN HIPOTESIS}

\section{Auditor Switching}

Auditor Switching merupakan perpindahan auditor (KAP) yang dilakukan oleh perusahaan klien. Bukti teoritis didasarkan pada teori agensi dan informasi ekonomi. Dalam kedua kasus, permintaan layanan audit muncul terutama dari adanya asimetri informasi. Dalam teori agensi, audit independen berfungsi untuk mengatur biaya agensi yang timbul dari perilaku mementingkan diri sendiri oleh agen (Nasser et al., 2006)

Pergantian auditor atau rotasi auditor dibagi menjadi pergantian yang bersifat sukarela dan pergantian yang 
bersifat wajib. Biasanya, pergantian auditor yang bersifat sukarela disebabkan keinginan klien yang sedang mengalami kebangkrutan, melakukan penawaran saham ke pasar modal, dan melakukan perubahan atas presentase kepemilikan sahamnya. Penyebab dari hal ini antara lain adalah audit fee, kualitas audit, dan opini audit. Penyebabnya antara lain yaitu audit fee, kualitas audit, dan opini audit. Sebaliknya, apabila pergantian auditor dikarenakan adanya kewajiban, maka hal tersebut terjadi karena memang dipersyaratkan oleh peraturan yang berkaitan dengan entitas bisnis. Terkait dengan hal tersebut auditor perlu memahami bisnis klien sebelum melakukan perikatan audit (Alisa, Devi \& Brillyandra, 2019).

Penelitian Haskins \& Williams (1990) menguji faktor - faktor mempengaruhi auditor changes antar big eight. Auditor changes tersebut bersifat kontinjen dengan metode RPA (Recursive Partitioning Algorithm) artinya yang mempengaruhi auditor tergantung situasinya. Faktor - faktor tersebut adalah faktor klien (client-related factors), yaitu: kesulitan keuangan, manajemen yang gagal, perubahan ownership, Initial Public Offering (IPO) dan faktor auditor (auditorrelated factors), yaitu: fee audit dan kualitas audit.

\section{Pergantian Manajemen}

Menurut Wijayani \& Januarti (2011) pergantian manajemen memiliki arti yang dapat dilihat dari pergantian Chief Executive Officer (CEO) perusahaan. Sedangkan Damayanti dan Sudarma (2007) mengemukakan bahwa pergantian manajemen merupakan pergantian Direksi perusahaan yang merupakan keputusan Rapat Umum Pemegang Saham (RUPS) atau Direksi mengajukan berhenti karena kemauan sendiri. Adanya manajemen yang baru mungkin juga diikuti oleh perubahan kebijakan dalam bidang akutansi, keuangan, dan pemilihan KAP. Dalam kondisi ini, manajer yang baru membutuhkan auditor yang mampu memenuhi tuntutan pertumbuhan perusahaan yang cepat.
Teori yang berkaitan dengan pergantian manajemen adalah teori agensi. Anthony dan Govindarajan (2012) menyatakan bahwa hubungan agensi ada ketika salah satu pihak (principle) menyewa pihak lain (agent) untuk melaksanakan suatu jasa dan dalam melakukan hal itu, mendelegasikan wewenang untuk membuat keputusan kepada agen tersebut. Hubungan antara auditor dengan klien merupakan hubungan timbal balik, dimana klien menyewa jasa auditor untuk mengaudit laporan keuangannya sehingga laporan tersebut dapat diandalkan dan relevan sehingga dapat menarik investor, sedangkan auditor harus secara profesional dalam mengaudit laporan keuangan klien serta mengungkapkan secara transparan dan objektif. Jika manajemen menilai auditor tidak kompeten dalam melaksanakan tugasnya, tentu akan membuat manajemen berpikir untuk melakukan auditor switching.

\section{Opini Audit}

Tanggung jawab jasa audit atas laporan keuangan perusahaan publik terletak pada laporan auditor independen yang merupakan bentuk komunikasi antara auditor dengan pengguna laporan keuangan. Pengguna laporan keuangan membutuhkan laporan auditor untuk mengetahui apakah informasi yang disajikan dalam laporan keuangan perusahaan dapat dipercaya atau tidak, sehingga dapat mengambil keputusan secara tepat.

Standar Profesional Akuntan Publik (SPAP) dalam Standar Audit (SA) 700 tentang Perumusan Suatu Opini menyatakan bahwa auditor harus merumuskan suatu opini tentang apakah laporan keuangan disusun, dalam semua hal yang material, sesuai dengan kerangka pelaporan keuangan yang berlaku.

Menurut SPAP terdapat 2 (dua) jenis opini auditor, yaitu:

1. Opini Tanpa Modifikasian

2. Opini Modifikasian

Auditor harus menyatakan opini tanpa modifikasian bila auditor 
menyimpulkan bahwa laporan keuangan disusun, dalam semua hal yang material, sesuai kerangka laporan keuangan yang berlaku (SA 700 Par 16).

SA 700 juga menyatakan bahwa jika auditor:

a) Menyimpulkan bahwa, berdasarkan bukti yang diperoleh, laporan keuangan tidak bebas dari kesalahan penyajian material; atau

b) Tidak dapat memperoleh bukti yang cukup dan tepat untuk menyimpulkan bahwa laporan keuangan secara keseluruhan bebas dari kesalahan penyajian material;

Auditor harus memodifikasi opininya dalam laporan auditor berdasarkan SA 705 tentang Modifikasi terhadap Opini.

Adapun tipe modifikasi terhadap opini auditor sendiri terdapat 3 (jenis), yaitu Opini Wajar dengan Pengecualian, Opini Tidak Wajar dan Opini Tidak Menyatakan Pendapat.

Berikut merupakan ilustrasi bagaimana pertimbangan auditor tentang sifat hal-hal yang menimbulkan modifikasi terhadap opini audit.

\section{Tabel 1.}

Pertimbangan Auditor tentang Sifat Hal Hal yang menimbulkan Modifikasi terhadap Opini Audit

\begin{tabular}{|c|c|c|}
\hline \multirow{2}{*}{$\begin{array}{c}\text { Penyebab Modifikasi } \\
\text { Opini Audit }\end{array}$} & $\begin{array}{c}\text { Pertimbangan auditor tentang } \\
\text { seberapa luas dampak atau } \\
\text { kemungkinan dampak terhadap } \\
\text { laporan keuangan }\end{array}$ \\
\cline { 2 - 3 } & $\begin{array}{c}\text { Material } \\
\text { tetapi tidak } \\
\text { pervasif }\end{array}$ & $\begin{array}{c}\text { Material dan } \\
\text { pervasif }\end{array}$ \\
\hline $\begin{array}{c}\text { Laporan keuangan } \\
\text { yang mengandung } \\
\text { salah saji material }\end{array}$ & $\begin{array}{c}\text { Opini Wajar } \\
\text { dengan } \\
\text { Pengecualian }\end{array}$ & $\begin{array}{c}\text { Opini Tidak } \\
\text { Wajar }\end{array}$ \\
\hline $\begin{array}{c}\text { Auditor tidak } \\
\text { memperoleh bukti } \\
\text { audit yang cukup } \\
\text { dan tepat }\end{array}$ & $\begin{array}{c}\text { Opini Wajar } \\
\text { dengan } \\
\text { Pengecualian }\end{array}$ & $\begin{array}{c}\text { Opini Tidak } \\
\text { Menyatakan } \\
\text { Pendapat }\end{array}$ \\
\hline
\end{tabular}

\section{Ukuran Perusahaan}

Menurut Brigham dan Houston (2011:117), ukuran perusahaan adalah rata-rata total penjualan bersih untuk tahun yang bersangkutan sampai beberapa tahun kemudian. Dalam hal penjualan lebih besar daripada biaya variabel dan biaya tetap, maka akan diperoleh jumlah pendapatan sebelum pajak. Sebaliknya, jika penjualan lebih kecil daripada biaya variabel dan tetap maka perusahaan akan mengalami kerugian.

Sesuai dengan Keputusan Ketua BAPEPAM No. IX.C.7 tentang pedoman mengenai bentuk dan isi pernyataan pendaftaran dalam rangka penawaran umum oleh perusahaan menengah dan kecil, menyatakan bahwa perusahaan besar adalah badan hukum yang didirikan di Indonesia yang memiliki jumlah kekayaan (total aset) tidak lebih dari Rp. 100.000.000.000,00 (seratus miliar rupiah), bukan merupakan afiliasi atau dikendalikan oleh suatu perusahaan yang bukan perusahaan menengah atau kecil, dan bukan merupakan reksa dana. Sedangkan penawaran umum oleh perusahaan menengah atau kecil adalah penawaran umum sehubungan dengan efek yang ditawarkan oleh perusahaan menengah atau kecil, di mana nilai keseluruhan efek yang ditawarkan tidak lebih dari Rp. 40.000.000.000,00 (empat puluh miliar rupiah). Hal ini berarti ukuran perusahaan menurut keputusan ketua BAPEPAM No. IX.C.7 dapat diartikan sebagai suatu ukuran dengan mengklasifikasikan besar kecilnya perusahaan dengan berbagai cara antara lain dinyatakan dalam total aset, nilai pasar saham, dan lain-lain.

Menurut Machfoedz (1994) pada dasarnya ukuran perusahaan hanya terbagi pada 3 (tiga) kategori, yaitu perusahaan besar (large firm), perusahaan menengah (medium size), dan perusahaan kecil (small firm). Penentuan perusahaan ini didasarkan pada total aset perusahaan dengan pengelompokkan sebagai berikut:

a. Perusahaan Besar

Perusahaan besar adalah perusahaan yang memiliki kekayaan bersih lebih besar dari Rp 10 Milyar termasuk tanah dan bangunan. Memiliki penjualan lebih dari Rp 50 Milyar/tahun.

b. Perusahaan Menengah

Perusahaan menengah adalah perusahaan yang memiliki kekayaan bersih Rp 1-10 Milyar termasuk tanah dan bangunan. Memiliki hasil 
penjualan lebih besar dari Rp 1 Milyar dan kurang dari Rp 50 Milyar.

c. Perusahaan Kecil

Perusahaan kecil adalah perusahaan yang memiliki kekayaan bersih paling banyak Rp 200 juta tidak termasuk tanah dan bangunan dan memiliki hasil penjualan minimal Rp 1 Milyar/tahun.

\section{Financial Distress}

Financial distress merupakan kondisi perusahaan yang sedang dalam keadaan kesulitan keuangan. Berbagai penilaian yang telah dilakukan oleh para peneliti atas kondisi ini memunculkan beragam pandangan mengenai pengertian kondisi financial distress.

Ross, Westerfield \& Jeff (2013) mendefinisikan financial distress sebagai suatu keadaan dimana arus kas operasi perusahaan tidak cukup untuk memenuhi kewajibannya saat ini (seperti kredit perdagangan atau beban bunga) dan perusahaan dipaksa untuk mengambil tindakan korektif.

Sedangkan Beaver, Correia \& McNichols (2012) menyatakan bahwa financial distress adalah kesulitan keuangan yang mengacu pada ketidakmampuan perusahaan dalam membayar obligasi ketika telah jatuh tempo.

Menurut Khasanah \& Nahumury (2013) tingkat hutang yang tinggi akan berdampak pada semakin tingginya beban perusahaan kepada kreditur, yang terlihat dari debt equity ratio (DER) yang tinggi dan kondisi seperti ini akan membuat perusahaan mengalami financial distress. Terjadinya kesulitan keuangan dalam suatu perusahaan dapat mencerminkan ketidakmampuan perusahaan untuk bertahan dan bertahan dengan segala kondisi permasalahan yang dihadapi perusahaan dalam dunia bisnis.

Dari beberapa pengertian yang telah dikemukakan diatas maka dapat dikatakan bahwa financial distress atau kesulitan keuangan adalah kondisi suatu perusahaan yang berada dalam tahap penurunan kinerja keuangan dimana perusahaan tidak dapat memenuhi kewajiban - kewajiban perusahaan, seperti pembayaran obligasi, kredit, atau beban bunga, sehingga perusahaan perlu mengambil langkah korektif agar kondisi tersebut tidak berlangsung secara terus menerus.

\section{Reputasi Auditor}

KAP adalah badan usaha yang didirikan berdasarkan ketentuan peraturan perundang-undangan dan mendapatkan izin usaha berdasarkan Undang-Undang, dalam hal ini adalah UU No. 5 Tahun 2011 tentang Akuntan Publik.

Salah satu peran KAP pada perusahaan adalah untuk memberikan jasa audit atas laporan keuangan historis perusahaan. Pemberian opini oleh auditor atas laporan keuangan perusahaan meliputi kewajaran penyajian laporan keuangan berdasarkan Prinsip Akuntansi yang berlaku umum. Kualitas audit yang dilaksanakan oleh akuntan publik dapat dinilai dari ukuran KAP yang melaksanakan proses audit. KAP besar atau KAP Big Four dipandang akan melaksanakan proses audit dengan lebih berkualitas jika dibandingkan dengan KAP kecil atau KAP Non - Big Four (Ginting \& Fransisca, 2014).

Perusahaan akan mencari KAP yang kredibilitasnya tinggi untuk meningkatkan kredibilitas laporan keuangan di mata pemakai laporan keuangan itu (Halim, 1997). Expertise KAP merupakan salah satu atribut dalam servis KAP besar (Mardiyah, 2002). Adanya faktor expertise itu akan menentukan perubahan auditor oleh perusahaan sehingga perusahaan lebih memilih KAP besar.

Banyak perusahaan yang memilih menggunakan jasa KAP yang mempunyai reputasi baik untuk meningkatkan kredibilitas dari laporan keuangan. KAP dengan reputasi yang baik sering dikaitkan dengan the big four firms.

Reputasi auditor merupakan kepercayaan dari publik atas prestasi yang dimiliki oleh auditor. Reputasi auditor ini diproksikan dengan ukuran Kantor Akuntan Publik. KAP besar merupakan KAP yang termasuk dalam big four dimana KAP besar dianggap lebih mempunyai mutu audit yang lebih tinggi, sehingga kualitas audit yang diberikan juga lebih 
tinggi. Sedangkan KAP non big four mempunyai reputasi yang lebih rendah jika dibandingkan dengan KAP big four, kualitas audit yang diberikan juga akan lebih rendah (Arsianto \& Rahardjo, 2013).

\section{Pengembangan Hipotesis}

\section{Hubungan antara Perubahan Manajemen dengan Auditor Switching}

Pergantian manajemen perusahaan terjadi jika perusahaan mengubah jajaran Direksinya. Damayanti dan Sudarma (2007) menyatakan bahwa pergantian manajemen merupakan pergantian direksi perusahaan merupakan keputusan RUPS atau Direksi berhenti karena kemauan sendiri. Apabila perusahaan melakukan perubahan Direksi, maupun Dewan Komisaris, maka akan menimbulkan juga adanya perubahan dalam kebijakan perusahaan. Setiap manajemen memiliki gaya kepemimpinan dan tujuan masingmasing.

Jadi, apabila terdapat pergantian manajemen secara langsung atau tidak langsung mendorong auditor switch karena manajemen perusahaan yang baru cenderung akan mencari KAP yang sesuai dengan kebijakan - kebijakan manajemen. Dengan demikian hipotesis dalam penelitian ini adalah sebagai berikut:

H1: Pergantian manajemen berpengaruh positif terhadap auditor switching.

\section{Hubungan antara Opini Audit dengan Auditor Switching}

Setelah mengaudit laporan keuangan klien, auditor memberikan opininya terhadap laporan keuangan tersebut. Opini yang diberikan oleh auditor dapat mempengaruhi pengambilan keputusan yang dilakukan oleh para pihak yang berkepentingan, misalnya investor. Investor akan merasa lebih yakin untuk menanamkan modalnya pada perusahaan yang memiliki opini Wajar Tanpa Pengecualian (WTP) pada laporan keuangan.

Jika auditor tidak dapat memberikan opini WTP (tidak sesuai dengan harapan perusahaan), perusahaan akan berpindah
KAP yang mungkin dapat memberikan opini sesuai dengan yang diharapkan perusahaan (Damayanti \& Sudarma, 2007). Manajemen tidak akan melanjutkan perikatan dengan auditor atas opini yang tidak diharapkan perusahaan atas laporan keuangannya dan berharap untuk mendapatkan auditor yang lebih lunak. Dengan demikian hipotesis dalam penelitian ini adalah sebagai berikut:

H2: Opini Audit berpengaruh positif terhadap Auditor Switching.

\section{Hubungan antara Ukuran Perusahaan dengan Auditor Switching}

Sinason et al., (2001:4) mengemukakan bahwa perusahaan besar mungkin memerlukan biaya awal yang lebih besar untuk auditor baru. Kenaikan biaya (baik langsung dan tidak langsung) dapat menyebabkan peningkatan hubungan auditor - klien, sehingga meningkatkan penguasaan auditor. Klien juga dikenai biaya awal saat terlibat auditor baru. Misalnya, personil klien banyak menghabiskan waktu dengan auditor baru untuk memberikan informasi mengenai bisnis klien. $\mathrm{Hal}$ itu menimbulkan biaya tidak langsung ketika membina hubungan baru dengan auditor baru.

Auditee yang lebih besar, karena kompleksitas operasi mereka dan peningkatan pemisahan antara manajemen dan kepemilikan, sangat memerlukan KAP yang dapat mengurangi agency cost dan ancaman kepentingan pribadi auditor (Hudaib \& Cooke, 2005). Hal ini berarti, ukuran perusahaan klien besar memiliki kecenderungan lebih rendah untuk berganti auditor dibandingkan klien yang kecil. Dengan demikian hipotesis dalam penelitian ini adalah sebagai berikut:

H3: Ukuran Perusahaan berpengaruh negatif terhadap Auditor Switching.

\section{Hubungan antara Financial Distress dengan Auditor Switching}

Financial distress merupakan kondisi perusahaan yang sedang dalam keadaan kesulitan keuangan. Schwartz \& 
Menon (1985) menyatakan bahwa perusahaan yang bangkrut lebih sering berpindah KAP daripada perusahaan yang tidak bangkrut. Ketidakpastian dalam bisnis pada perusahaan-perusahaan yang terancam bangkrut (mempunyai kesulitan keuangan) menimbulkan kondisi yang mendorong perusahaan berpindah KAP. Tanda - tanda perusahaan yang mengalami financial distress dapat dilihat dari laporan keuangannya. Apabila kewajiban keuangan lebih besar daripada kekayaan maka dapat dikatakan bahwa perusahaan mengalami kesulitan keuangan. Maka dari itu, dapat dikatakan bahwa kesulitan keuangan secara signifikan berpengaruh terhadap perusahaan terancam bangkrut untuk berpindah KAP. Dengan demikian hipotesis dalam penelitian ini adalah sebagai berikut:

H4: Financial Distress berpengaruh positif terhadap Auditor Switching.

\section{Hubungan antara Reputasi Auditor dengan Auditor Switching}

Reputasi auditor ditandai dengan KAP yang memiliki sumber daya yang lebih besar dalam hal mengaudit dengan mempunyai kualitas audit yang baik secara konsisten dari waktu ke waktu. Reputasi auditor sangat mempengaruhi kredibilitas laporan keuangan perusahaan, karena pemakai jasa keuangan yakin bahwa auditor memiliki kemampuan dan independensi.

Untuk itu jika perusahaan telah menggunakan jasa KAP yang bereputasi, perusahaan tidak akan melakukan voluntary auditor switching karena KAP bereputasi ini dapat mendukung perkembangan perusahaan dalam mempertahankan kelangsungan hidupnya. Dengan demikian hipotesis dalam penelitian ini adalah sebagai berikut:

H5: Reputasi Auditor berpengaruh negatif terhadap Auditor Switching.

\section{Model Penelitian}

Berdasarkan kerangka teoritis serta pengembangan hipotesis, maka model penelitian yang diajukan seperti terlihat pada Gambar 1 berikut ini:

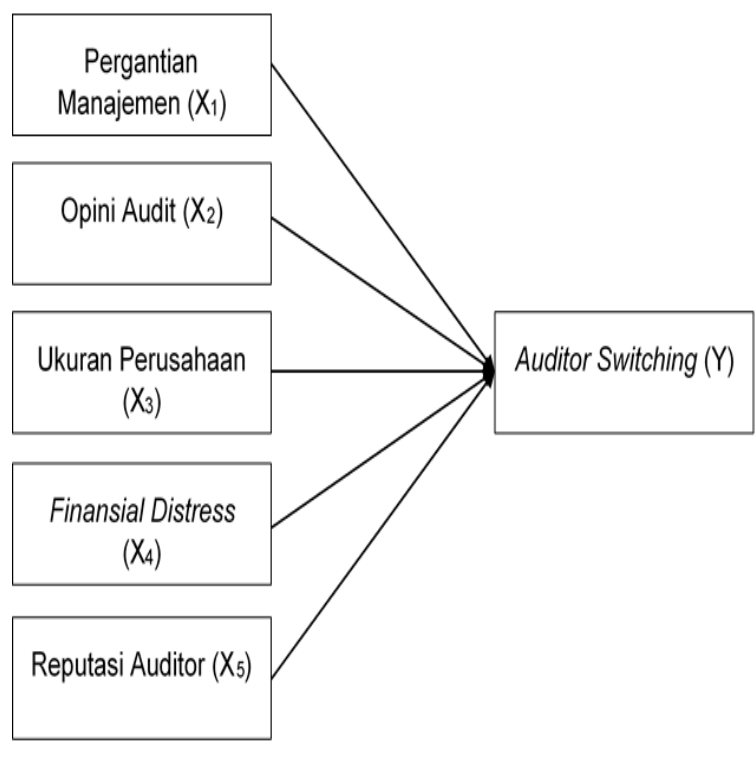

Gambar 1.

Kerangka Konseptual

\section{METODOLOGI PENELITIAN}

\section{Sampel Penelitian}

Penentuan sampel dalam penelitian ini menggunakan metode purposive sampling. Purposive sampling merupakan salah satu klasifikasi dalam desain sampling non probabilitas yang memenuhi beberapa kriteria dari kelompok tertentu untuk memperoleh informasi yang diperlukan (Uma Sekaran, 2013).

Alasan pemilihan sampel dengan menggunakan purposive sampling adalah karena tidak semua sampel memiliki kriteria sesuai dengan yang telah penulis tentukan. Oleh karena itu, sampel yang dipilih sengaja ditentukan berdasarkan kriteria tertentu yang telah ditentukan oleh penulis untuk mendapatkan sampel yang representatif. Adapun perusahaan yang dijadikan sampel dalam penelitian ini adalah perusahaan Manufaktur yang terdaftar di Bursa Efek Indonesia (BEI) periode 2016 - 2018 yang memenuhi kriteria tertentu dengan hasil sebagai berikut: 
Tabel 2.

Pemilihan sampel dengan purposive sampling

\begin{tabular}{|c|c|c|}
\hline No & Keterangan & Jumlah \\
\hline 1 & $\begin{array}{l}\text { Perusahaan Manufaktur yang } \\
\text { terdaftar di Bursa Efek Indonesia } \\
\text { (BEI) periode tahun 2016-2018 }\end{array}$ & 164 \\
\hline 2 & $\begin{array}{l}\text { Perusahaan Manufaktur yang } \\
\text { tidak menyajikan laporan } \\
\text { keuangan dalam satuan mata } \\
\text { uang rupiah selama periode } \\
\text { tahun 2016-2018 }\end{array}$ & (4) \\
\hline 3 & $\begin{array}{l}\text { Perusahaan Manufaktur yang } \\
\text { terdaftar di Bursa Efek Indonesia } \\
\text { yang tidak memliki kelengkapan } \\
\text { informasi yang di butuhkan } \\
\text { penelitian terkait dengan indikator } \\
\text { perhitungan yang dijadikan } \\
\text { variabel. }\end{array}$ & (37) \\
\hline 4 & $\begin{array}{l}\text { Perusahaan Manufaktur yang } \\
\text { terdaftar di Bursa Efek Indonesia } \\
\text { (BEI) periode 2016-2018 yang } \\
\text { delisting dan IPO Initial Public } \\
\text { Offering (IPO) }\end{array}$ & (14) \\
\hline & $\begin{array}{l}\text { Jumlah perusahaan yang terpilih } \\
\text { menjadi sampel }\end{array}$ & 109 \\
\hline \multicolumn{2}{|r|}{$\begin{array}{c}\text { Jumlah Observasi Data (3 tahun } x \\
109 \text { sampel) }\end{array}$} & 327 \\
\hline
\end{tabular}

\section{Pengukuran Variabel}

Penelitian ini menggunakan enam variabel yang terdiri dari lima variabel bebas (independen) dan satu variabel terikat (dependen). Variabel bebas dalam penelitian ini adalah perubahan manajemen, opini audit, ukuran perusahaan, financial distress dan reputasi auditor. Sedangkan variabel terikatnya adalah auditor switching.

\section{a. Auditor Switching}

Dalam penelitian ini, yang merupakan variabel terikat adalah auditor switching. Variabel ini diukur menggunakan dummy dengan nilai 1 diberikan jika perusahaan mengganti $\mathrm{KAP}$, dan 0 untuk perusahaan yang tidak mengganti KAP.

b. Perubahan Manajemen

Variabel independen perubahan manajemen diukur dengan menggunakan variabel dummy dengan nilai 1 diberikan jika perusahaan mengganti Direktur Utama (CEO), dan 0 untuk perusahaan yang tidak mengganti Direktur Utama (CEO).

c. Opini Audit

Variabel independen opini audit diukur menggunakan variabel dummy dengan nilai 1 diberikan jika perusahaan menerima opini selain wajar tanpa pengecualian, dan 0 untuk perusahaan yang menerima opini wajar tanpa pengecualian.

d. Ukuran Perusahaan

Variabel independen ukuran perusahaan menggunakan logaritma natural (Ln) atas total aset perusahaan.

e. Financial Distress

Variabel independen financial distress diukur dengan menggunakan Altman Z-score dengan formula $Z=$ $0,717 X 1+0,847 X 2+3,107 X 3+$ $0,420 \times 4+0,998 \times 5$.

f. Reputasi Auditor

Variabel reputasi auditor ini diukur dengan menggunakan variabel dummy, dengan nilai 1 diberikan jika perusahaan diaudit oleh KAP Big Four, dan 0 untuk perusahaan yang diaudit oleh KAP Non Big Four.

\section{Analisis Statistik}

Dalam penelitian ini penulis menggunakan regresi logistik logistik karena, dalam penelitian yang variabel dependenya bersifat kategorikal (nominal atau non metrik) dan variabel independennya kombinasi antara metrik dan non metrik menggunakan regresi logistik.

Menurut Ghozali (2013:79), model regresi logistik adalah model regresi yang perubah terikat/responnya mensyaratkan berupa perubah kategori. Variabel respon yang mempunyai dua kategori model regresi disebut biner logistik. Jika data hasil pengamatan dengan $\mathrm{X} 1, \mathrm{X} 2, \mathrm{X} 3, \mathrm{X} 4$, $X 5$ dengan variabel $Y$, dengan $Y$ mempunyai dua kemungkinan nilai 0 dan $1, Y=1$ menyatakan respon yang ditentukan dan sebaliknya $Y=0$ tidak memiliki kriteria maka $Y$ mengikuti distribusi.

Regresi logistik digunakan untuk menguji apakah terdapat pengaruh variabel pergantian manajemen, opini 
audit, ukuran perusahaan klien, financial distress, reputasi auditor terhadap auditor switching dengan persamaan sebagai berikut:

$$
\begin{gathered}
\log \left(\frac{P}{1-p}\right)=\beta_{0}+\beta_{1} X_{1}+\beta_{2} X_{2}+\beta_{3} X_{3}+\beta_{4} \\
X_{4}+\beta_{5} X_{5}
\end{gathered}
$$

dimana :

$\begin{array}{ll}\log \left(\frac{\mathrm{P}}{1-\mathrm{p}}\right) & : \text { Auditor Switching } \\ \beta_{0} & : \text { Konstanta } \\ \mathrm{X}_{1} & \text { : Pergantian Manajemen } \\ \mathrm{X}_{2} & \text { : Opini Audit } \\ \mathrm{X}_{3} & \text { : Ukuran Perusahaan } \\ \mathrm{X}_{4} & : \text { Financial Distress } \\ \mathrm{X}_{5} & \text { : Reputasi Auditor }\end{array}$

\section{HASIL DAN PEMBAHASAN}

\section{Model Regresi Logistik}

Tabel 3.

Hasil Model Logit

Variables in Equation

\begin{tabular}{|l|l|r|r|r|r|r|}
\hline \multicolumn{2}{|c|}{} & \multicolumn{1}{|c|}{ B } & S.E. & Wald & df & Sig. \\
\hline \multirow{4}{*}{$\begin{array}{l}\text { Step } \\
1 \text { a }\end{array}$} & X1 & 1.077 & .489 & 4.854 & 1 & .028 \\
\cline { 2 - 7 } & X2 & 2.618 & 1.046 & 6.263 & 1 & .012 \\
\cline { 2 - 7 } & X3 & .070 & .034 & 4.239 & 1 & .040 \\
\cline { 2 - 7 } & X5 & .319 & .127 & 6.314 & 1 & .012 \\
\cline { 2 - 8 } & Constant & -3.912 & .389 & 5.491 & 1 & .019 \\
\hline
\end{tabular}

Koefisien regresi logistik yang diperoleh seperti terlihat pada Tabel 3 diatas dinyatakan kedalam bentuk hubungan fungsional sebagai berikut:

$$
\begin{aligned}
\text { Logit } Y= & -3,907+1,077 X_{1}+2,618 X_{2}+ \\
& 0,070 X_{3}+0,319 X_{4}-0,912 X_{5}
\end{aligned}
$$

\section{Uji Kelayakan Model Regresi Logistik}

Untuk menilai kelayakan model regresi logistik digunakan pengujian Hosmer and Lemeshow's Goodness of Fit Test. Model regresi logistik dikatakan fit model (cukup baik) apabila nilai signifikansi uji Chi-Square diatas 0,05, dimana semakin mendekati 1 maka diartikan model akan semakin baik.
Tabel 4.

Hosmer and Lemeshow Test

\begin{tabular}{|l|r|r|l|}
\hline Step & Chi-square & df & Sig. \\
\hline 1 & 6.296 & 8 & .614 \\
\hline
\end{tabular}

Hasil perhitungan Hosmer and Lemeshow Test pada Tabel 4 menunjukkan nilai signifikansi dari uji Goodness-of-Fit (ChiSquare) sebesar 0,614. Nilai signifikansi > 0,05 berarti bahwa model cukup baik (fit model) untuk digunakan dalam memprediksi auditor switching $(\mathrm{Y})$.

\section{Penilaian Keseluruhan Model}

Untuk menilai model secara keseluruhan (overall model fit test) yang menunjukkan pengaruh variabel - variabel independen secara bersama-sama terhadap variabel dependen digunakan uji Log Likelihood. Pengujian secara keseluruhan ini menggunakan statistik uji Chi-Square. Kriteria uji dalam menggambil keputusan penilaian keseluruhan model yang digunakan adalah tolak Ho pada tingkat kepercayaan $(1-\propto \propto)$ jika $\chi_{\text {hitung }}^{2}>\chi_{(1-\alpha): p}^{2}$

Tabel 5.

Chi-Square Test

\begin{tabular}{|l|r|r|r|}
\multicolumn{5}{|c}{ Model Summary } \\
\hline Step & $\begin{array}{c}-2 \text { Log } \\
\text { likelihood }\end{array}$ & $\begin{array}{c}\text { Cox \& Snell } \\
\text { R Square }\end{array}$ & $\begin{array}{l}\text { Nagelkerke R } \\
\text { Square }\end{array}$ \\
\hline 1 & $247.252^{\mathrm{a}}$ & .075 & .133 \\
\hline
\end{tabular}

Dari tabel Chi-Square untuk tingkat error $(\alpha)$ sebesar $5 \%$ atau 0,05 dan derajat bebas $=5$ diperoleh $\chi_{(1-0.10) ; 5}^{2}=11,070$. Dan nilai Chi-Square hitung sebesar 247,252. Dikarenakan nilai Chi-Square hitung $>$ ChiSquare tabel $(247,252>11,070)$, maka dapat disimpulkan bahwa secara bersama-sama variabel pergantian manajemen (X1), opini audit (X2), ukuran perusahaan (X3), financial distress (X4) dan reputasi auditor (X5) berpengaruh bermakna (signifikan) terhadap auditor switching $(\mathrm{Y})$. 


\section{Pengujian Hipotesis}

Pengujian hipotesis di atas menggunakan statistik uji Wald yang mempunyai (pendekatan) distribusi ChiSquare dengan kriteria pengujian adalah tolak $\mathrm{H}_{0}$ pada $\alpha(5 \%$ atau 0,05$)$ yang ditetapkan jika $w>\chi_{(1-\alpha): 1}^{2}$.

\section{Hubungan antara Perubahan Manajemen dengan Auditor Switching}

Tabel 6.

Hasil Pengujian Koefisien Regresi $X_{1}-Y$

\begin{tabular}{|c|c|c|c|c|}
\hline Hipotesis & $\begin{array}{c}\text { Koefisien } \\
\text { Regresi }\end{array}$ & Wald & $\chi^{2}$ tabel & sig \\
\hline$\beta_{1 \neq 0}$ & 1,077 & 4,854 & 3,841 & 0,028 \\
\hline
\end{tabular}

Dari tabel 5.14 dapat dilihat bahwa variabel pergantian manajemen $\left(X_{1}\right)$ memiliki koefisien regresi positif sebesar 1,077. Hal ini menunjukkan bahwa perusahaan yang melakukan pergantian manajemen akan meningkatkan kemungkinan untuk mengganti KAP nya.

Variabel pergantian manajemen $\left(\mathrm{X}_{1}\right)$ memiliki nilai uji Wald sebesar 4,854 dan nilai signifikansi sebesar 0,028. Jika dibandingkan dengan taraf signifikansi 0,05 atau (5\%), maka nilai signifikansi lebih kecil dari a atau $(0,028<0,05)$. Artinya dapat disimpulkan bahwa $\mathrm{H}_{0}$ ditolak. Dengan demikian variabel pergantian manajemen $\left(X_{1}\right)$ berpengaruh positif terhadap auditor switching $(\mathrm{Y})$. Hal ini berarti sesuai dengan teori agensi yang mengasumsikan bahwa manusia itu memiliki sifat self interest, maka pihak agen lebih cenderung memilih KAP yang sesuai dengan keinginan agen.

Hasil ini sesuai dengan penelitian Wijayani \& Januarti (2011) dan Alisa, Devi \& Brillyandra (2019) yang juga menemukan bukti bahwa pergantian manajemenberpengaruh secara signifikan terhadap auditor switching.

\section{Hubungan antara Opini Audit dengan Auditor Switching}

Tabel 7.

Hasil Pengujian Koefisien Regresi $X_{2}-Y$

\begin{tabular}{|c|c|c|c|c|}
\hline Hipotesis & $\begin{array}{c}\text { Koefisien } \\
\text { Regresi }\end{array}$ & Wald & $\chi^{2}$ tabel & sig \\
\hline$\beta_{1} \neq 0$ & 2,618 & 6,263 & 3,841 & 0,012 \\
\hline
\end{tabular}

Dari Tabel 7 dapat dilihat bahwa variabel opini audit $\left(X_{2}\right)$ memiliki koefisien regresi positif sebesar 2,618. Hal ini menunjukkan bahwa perusahaan cenderung berpindah KAP setelah menerima qualified opinion atas laporan keuangannya.

Variabel opini audit $\left(X_{2}\right)$ memiliki nilai uji Wald sebesar 6,263 dan nilai signifikansi sebesar 0,012. Jika dibandingkan dengan taraf signifikansi 0,05 atau (5\%), maka nilai signifikansi lebih kecil dari a atau $(0,012<0,05)$. Artinya dapat disimpulkan bahwa $\mathrm{HO}$ ditolak. Dengan demikian variabel opini audit $\left(X_{2}\right)$ berpengaruh positif terhadap auditor switching $(\mathrm{Y})$.

Hasil ini sesuai dengan penelitian Divianto (2011) menemukan bukti empiris bahwa opini auditmeningkatkan tingkat auditor switching, sedangkan penelitian yang dilakukan oleh Chadegani et al., (2011) menemukan bahwa opini audit tidak berpengaruh secara signifikan pada perusahaan go public di Malaysia. Jika auditor tidak dapat memberikan opini wajar tanpa pengecualian (tidak dengan harapan perusahaan), perusahaan akan berpindah KAP yang mungkin dapat memberikan opini sesuai dengan yang diharapkan perusahaan (Damayanti dan Sudarma, 2007).

\section{Hubungan antara Ukuran Perusahaan dengan Auditor Switching}

Tabel 8.

Hasil Pengujian Koefisien Regresi $X_{3}-Y$

\begin{tabular}{|c|c|c|c|c|}
\hline Hipotesis & $\begin{array}{c}\text { Koefisien } \\
\text { Regresi }\end{array}$ & Wald & $\chi^{2}$ tabel & sig \\
\hline$\beta_{1 \neq 0}$ & 0,070 & 4,239 & 3,841 & 0,040 \\
\hline
\end{tabular}

Dari Tabel 8 dapat dilihat bahwa variabel ukuran perusahaan $\left(X_{3}\right)$ memiliki koefisien regresi positif sebesar 0,070 yang menunjukkan bahwa perusahaan dengan ukuran perusahaan yang lebih besar cenderung akan berpindah KAP. Hal ini berbeda dengan hipotesis awal bahwa semakin besar ukuran perusahaan maka akan cenderung tidak melakukan auditor switching. 
Variabel ukuran perusahaan $\left(\mathrm{X}_{3}\right)$ memiliki nilai uji Wald sebesar 4,239 dan nilai signifikansi sebesar 0,070. Jika dibandingkan dengan taraf signifikansi 0,05 atau (5\%), maka nilai signifikansi lebih kecil dari a atau $(0,040<0,05)$. Artinya dapat disimpulkan bahwa $\mathrm{H}_{0}$ ditolak. Dengan demikian variabel ukuran perusahaan $\left(X_{3}\right)$ berpengaruh positif terhadap auditor switching $(\mathrm{Y})$.

Hasil penelitian ini tidak mendukung hasil penelitian sebelumnya yang dilakukan oleh Nasser et al (2006). Klien klien dengan total aset kecil tidak cenderung berpindah - pindah KAP, karena klien sudah merasa cocok dengan laporan yang diberikan oleh auditornya.

\section{Hubungan antara Financial Distress dengan Auditor Switching}

Tabel 9.

Hasil Pengujian Koefisien Regresi $X_{4}-Y$

\begin{tabular}{|c|c|c|c|c|}
\hline Hipotesis & $\begin{array}{c}\text { Koefisien } \\
\text { Regresi }\end{array}$ & Wald & $\chi^{2}$ tabel & sig \\
\hline$\beta_{1} \neq 0$ & 0,319 & 6,314 & 3,841 & 0,012 \\
\hline
\end{tabular}

Dari Tabel 9 dapat dilihat bahwa variabel financial distress $\left(\mathrm{X}_{4}\right)$ memiliki koefisien regresi positif sebesar 0,319 . Hal ini menunjukkan bahwa semakin tinggi financial distress pada suatu perusahaan maka mendorong perusahaan berpindah KAP.

Variabel financial distress $\left(\mathrm{X}_{4}\right)$ memiliki nilai uji Wald sebesar 6,314 dan nilai signifikansi sebesar 0,012. Jika dibandingkan dengan taraf signifikansi 0,05 atau (5\%), maka nilai signifikansi. lebih kecil dari a atau $(0,012<0,05)$. Artinya dapat disimpulkan bahwa $\mathrm{H}_{0}$ ditolak. Dengan demikian variabel financial distress $\left(\mathrm{X}_{4}\right)$ berpengaruh positif terhadap auditor switching $(\mathrm{Y})$.

Hasil penelitian ini konsisten dengan penelitian Schwartz \& Menon (1985) dan Schwartz \& Soo (1995) yang menyatakan bahwa menyatakan bahwa perusahaan yang bangkrut lebih sering berpindah auditor daripada perusahaan yang tidak bangkrut.

\section{Hubungan antara Reputasi Auditor dengan Auditor Switching}

Tabel 10.

Hasil Pengujian Koefisien Regresi $X_{5}-Y$

\begin{tabular}{|c|c|c|c|c|}
\hline Hipotesis & $\begin{array}{c}\text { Koefisien } \\
\text { Regresi }\end{array}$ & Wald & $\chi^{2}$ tabel & sig \\
\hline$\beta_{1} \neq 0$ & $-0,912$ & 5,491 & 3,841 & 0,019 \\
\hline
\end{tabular}

Dari Tabel 10 dapat dilihat bahwa variabel reputasi auditor $\left(X_{5}\right)$ memiliki koefisien regresi negatif sebesar $-0,912$. $\mathrm{Hal}$ ini menunjukkan semakin tinggi reputasi auditor pada suatu perusahaan maka perusahaan cenderung tidak berpindah KAP.

Variabel reputasi auditor $\left(\mathrm{X}_{5}\right)$ memiliki nilai uji Wald sebesar 5,491 dan nilai signifikansi sebesar 0,019. Jika dibandingkan dengan taraf signifikansi 0,05 atau (5\%), maka nilai signifikansi lebih kecil dari a atau $(0,019<0,05)$. Artinya dapat disimpulkan bahwa $\mathrm{H}_{0}$ ditolak. Dengan demikian variabel reputasi auditor $\left(X_{5}\right)$ berpengaruh negatif terhadap auditor switching $(\mathrm{Y})$.

Hal ini konsisten dengan penelitian Prahartari (2013) dan Alisa, Devi \& Brillyandra (2019) yang menunjukkan semakin tinggi reputasi auditor pada suatu perusahaan maka perusahaan cenderung tidak berpindah KAP.

\section{Hasil Uji Simultan}

Koefisien determinasi digunakan untuk mengetahui besar persentase pengaruh dari variabel independen terhadap variabel dependen. Dalam regresi logistik nilai koefisien determinasi ditunjukkan dengan nilai Cox \& Snell $R$ Square atau Nagelkerke $R$-Square. Koefesien determinasi pada model regresi logistik dalam penelitian ini menggunakan nilai Nagelkerke $R$ Square. Nagelkerke $R$ Square merupakan modifikasi dari koefisien Cox dan Snell untuk memastikan bahwa nilainya diantara 0 (nol) sampai 1 (satu).

Tabel 11.

Hasil Pengujian Simultan

\begin{tabular}{|c|c|r|r|}
\multicolumn{5}{|c}{ Model Summary } \\
\hline Step & $\begin{array}{c}-2 \text { Log } \\
\text { likelihood }\end{array}$ & $\begin{array}{c}\text { Cox \& Snell R } \\
\text { Square }\end{array}$ & $\begin{array}{c}\text { Nagelkerke R } \\
\text { Square }\end{array}$ \\
\hline 1 & 247.252 & .075 & .133 \\
\hline
\end{tabular}


Koefisien determinasi ditunjukkan oleh nilai koefisien Nagelkerke $R$-Square, berdasarkan table di atas, diketahui nilai memiliki nilai Nagelkerke $R$-Square sebesar 0,133. Hal ini menunjukkan pergantian manajemen $\left(X_{1}\right)$, opini audit $\left(X_{2}\right)$, ukuran perusahaan $\left(X_{3}\right)$, financial distress $\left(\mathrm{X}_{4}\right)$ dan reputasi auditor $\left(\mathrm{X}_{5}\right)$ berpengaruh terhadap auditor switching (Y) sebesar $13,3 \%$. Sedangkan sisanya yaitu sebesar $86,7 \%$ dipengaruhi oleh faktor - faktor lain yang tidak dimasukkan ke dalam model penelitian.

\section{KESIMPULAN}

Penelitian ini menguji pengaruh perubahan manajemen, opini audit, ukuran perusahaan, financial distress dan reputasi auditor terhadap auditor switching pada perusahaan manufaktur yang terdaftar di Bursa Efek Indonesia (BEI) pada tahun 2016 - 2018. Penelitian ini menemukan bahwa perubahan manajemen, opini audit, financial distress dan reputasi auditor berpengaruh terhadap auditor switching. Akan tetapi penelitian ini tidak berhasil menemukan hubungan negatif antara ukuran perusahaan terhadap auditor switching yang berarti perusahaan dengan total aset kecil tidak cenderung berpindah - pindah $\mathrm{KAP}$, karena klien sudah merasa cocok dengan laporan yang diberikan oleh auditornya.

Hasil pengujian secara simultan menemukan bahwa variabel perubahan manajemen, opini audit, ukuran perusahaan, financial distress dan reputasi auditor berpengaruh sebesar $13,3 \%$ terhadap auditor switching, sedangkan sisanya dipengaruhi oleh faktor - faktor lain.

\section{IMPLIKASI DAN KETERBATASAN}

Penelitian ini memiliki beberapa keterbatasan penelitian. Pertama dampak dari pemberlakuan PP No. 20 tahun 2015 tentang Praktik Akuntan Publik belum diteliti secara terinci. Penelitian ini menggunakan basis data perusahaan manufaktur yang listed di BEI tanpa melibatkan data primer sehingga penelitian ini belum memberikan hasil yang komprehensif. Kedua, penelitian ini hanya menguji pengaruh variabel variabel pergantian manajemen, opini audit, ukuran perusahaan, financial distress dan reputasi audit terhadap pergantian KAP. Variabel - variabel lain yang mungkin berpengaruh juga terhadap pergantian KAP tidak diuji dalam penelitian ini. Selain itu pengukuran variabel reputasi auditor menggunakan proksi KAP Big Four dan Non Big Four kurang dapat menggambarkan secara tepat mengenai reputasi audit dan perlu dikaji kembali.

Penelitian selanjutnya dapat menggunakan variabel - variabel lain seperti karakteristik corporate governance dan audit fee, yang dapat meningkatkan pengetahuan mengenai audit tenure dan auditor switching. Selain itu belum berhasilnya penelitian ini untuk membuktikan hipotesis mengenai hubungan negatif ukuran perusahaan terhadap audit switching dapat diperbaiki pada penelitian berikutnya dengan melakukan penambahan sampel dan periode observasi.

\section{REFERENCES}

Alisa, I.A., Devi, I.A., \& Brillyandra, F. (2019). The Effect of Audit Opinion, Change of Management, Financial Distress and Size of A Public Accounting Firm on Auditor Switching. Jurnal Akuntansi Trisakti ISSN: 2339-0832 (Online) Volume. 6 Nomor. 1 Februari 2019:55-68.

Anthony, Robert N, dan Vijay Govindarajan. (2012). Management Control System. Jakarta: Salemba Empat.

BAPEPAM. (1997). Keputusan Ketua BAPEPAM No. Kep-11/PM/1997 Tentang Perubahan No. IX.C.7 Tentang Pedoman Mengenai Bentuk \& Isi Pernyataan Pendaftaran dalam Rangka Penawaran Umum oleh Perusahaan Menengah atau Kecil.

Beaver H. William, Maria Correia, Maureen McNichols. (2011). Financial Statement Analysis and the Prediction of 
Financial Distress. Hannover: Now Publishers Inc.

Brigham dan Houston. 2011. Dasar-Dasar Manajemen Keuangan (II). Edisi ke 11. Jakarta. Salemba Empat.

Carpenter, Charles G. \& Strawser, Robert H. (1971). Displacement of Auditors When Clients Go Public. Journal of Accountancy, Juni: 55-58.

Chadegani, Arezoo Aghaei, Mohamed, Zakiah Muhammaddun dan Azam Jari. (2011). The Determinant Factors of Auditor Switch among Companies Listed on Tehran Stock Exchange. International Conference on Sociality and Economics Development. IPEDR vol.10.

Damayanti, S., \& Sudarma, M. (2007). Faktor - Faktor yang Mempengaruhi Perusahaan Berpindah KAP. Simposium Nasional Akuntansi XI 2008, Pontianak.

Divianto. (2011). "Faktor-Faktor yang Mempengaruhi Perusahaan dalam Melakukan Auditor Switch (Studi Kasus: Perusahaan Manufaktur di BEI)". Jurnal Ekonomi dan Informasi Akuntansi, Vol. 1 No. 2

Ghozali, Imam. (2013). "Aplikasi Analisis Multivariate Dengan Program SPSS". Semarang: Badan Penerbit Universitas Diponegoro.

Ginting, S., \& Fransisca, E. (2014). Analisis Faktor-Faktor yang Mempengaruhi Pergantian Kantor Akuntan Publik Pada Perusahaan Manufaktur di Bursa Malaysia. Jurnal Wira Ekonomi Mikroskil, 4(1), 1-10.

Halim, A., 1997, Dasar-dasar Audit Laporan Keuangan. Unit Penerbit \& Percetakan (UPP) AMP YKPN: Yogyakarta.

Haskins, Mark E. \& Williams, David, D. (1990). A Contingent Model of Intra Big Eight Auditor Changes. Auditing: A Journal of Practice and Theory, Vol. 9, No. 3, Fall, h.55-74.

Hudaib, Mohammad \& T.E Cooke. (2005). The Impact of Managing Director Changes and Financial Distress on Audit Qualification and Auditor Switching,
Journal of Business Finance \& Accounting, 32(9) \& (10), November/December 2005.

Hudaib, Mohammad dan T.E Cooke. (2005). The Impact of Managing Director Changes and Financial Distress on Audit Qualification and Auditor Switching, Journal of Business Finance \& Accounting, 32(9) \& (10), November/December 2005.

Institusi Akuntan Publik. (2013). "Standar Profesional Akuntan Publik Indonesia”. Jakarta. Salemba Empat.

Institusi Akuntan Publik. (2020). "Kode Etik Profesional Akuntan Publik”. Jakarta.

Ismail, Shahnaz. Aliahmed, Huson Joher. Nassir, Annuar Md. \& Hamid, Mohamad Ali Abdul. (2008). Why Malaysian Second Board Companies Switch Auditors: Evidence of Bursa Malaysia. International Research Journal of Finance and Economics. Volume XIII: 123-130.

Jensen, M. C., \& Meckling, W. H. (1976). Theory of the Firm: Managerial Behavior, Agency Costs and Ownership Structure. Journal of Financial Economics, 3, 305360.

Kawijaya, Nelly \& Juniarti. (2002). Faktor Faktor yang Mendorong Perpindahan Auditor (Auditor Switch) pada Perusahaan - Perusahaan di Surabaya dan Sidoarjo. Jurnal Akuntansi dan Keuangan Vol. 4, No. 2.

Khasanah, I., \& Nahumury, J. (2013). The Factors Affecting Auditor Switching in Manufacturing Companies Listed in Indonesia Stock Exchange (BEI). The Indonesia Accounting Review Vol. 3, No. 2 , 203-212.

Mardiyah, A.A., (2002). Pengaruh Perubahan Kontrak, Keefektifan Auditor, Reputasi Klien, Biaya Audit, Faktor Klien dan Faktor Auditor Terhadap Auditor Changes: Sebuah Pendekatan Dengan Model Kontinjensi RPA. Seminar Nasional Akuntansi V, Semarang.

Mas'ud Machfoedz. (1994). Financial Ratio Characteristic Analysis and The Prediction of Earnings Changes in Indonesia. Kelola No. 7:114-133. 
Menteri Keuangan, (2008). Peraturan Menteri Keuangan Republik Indonesia Nomor 17/PMK.01/2008 tentang "Jasa Akuntan Publik". Jakarta.

Nasser, Abu T. Wahid, Emelin A. Nazri, Sharifah N. F. S. M. \& Hudaib, Mohammad. (2006). Auditor-Client Relationship: The Case of Audit Tenure and Auditor Switching in Malaysia. Managerial Auditing Journal. Volume XXI (7), p. 724-737.

Prahartari, F. A. (2013). AnalisisFaktorFaktor yang Mempengaruhi Auditor Switching. Jurnal Akuntansi Fakultas Ekonomi dan Bisnis Universitas Islam Negeri Syarif Hidayatullah, 5-105.

Presiden Republik Indonesia, (2015). "Peraturan Pemerintah Republik Indonesia Nomor 20 Tahun 2015 Tentang Praktek Akuntan Publik". Kementerian Sekretariat Negara: Jakarta.

Ross, Stephen A, Randolph W. Westerfield \& Jeffrey Jeff. (2013). Corporate Finance Tenth Edition. New York : McGraw-Hill.

Rossa Arsianto, M., \& Nur Rahardjo, S. (2013). Faktor - Faktor yang Mempengaruhi Penerimaan Opini Audit Going Concern. Diponegoro Journal of Accounting, 0, 572-579.

Schwartz, K.B. dan Soo, B.S., 1995, An Analysis of Form 8-K Disclosures of Auditor Changes by Firms Approaching Bankruptcy. Auditing: A Journal of Practice \& Theory, Vol. 14, No. 1, Spring 1995, 125 135.

Schwartz, Kenneth B. \& Menon, Krishnagopal. (1985). Auditor Switches by Failing Firms. The Accounting Review. April. Volume $X L$ (2), p.248-261.

Setyorini, N. Theresia \& A.Y. Ardiati. (2006). Pengaruh Potensi Kebangkrutan Perusahaan Publik Terhadap Pergantian Auditor. Kinerja, Vol. 10 No. 1, 75-86.

Sinason, D.H., J.P. Jones, \& S.W. Shelton. (2001). An Investigation of Auditor and Client Tenure. Mid-American Journal of Business, Vol. 16, (2), pp. 31-40.
Uma Sekaran, R. B. (2013). Research Method for Business: A Skill Building Approach Sixth Edition. Italy: Printer Trento Srl.

Undang-undang No. 5 Tahun 2011 tentang Akuntan Publik. Lembaran Negara Republik Indonesia No. 5215.

Wijayani, Evi \& Januarti, Indira. (2011). Analisis Faktor - Faktor yang Mempengaruhi Perusahaan dii Indonesia Melakukan Auditor Switching. Simposium Nasional Akuntansi XIV 2011, Aceh.

Willingham, John J. \& Carmichael. (1997). Perspectives in Auditing. New York: McGraw-Hill.

Woo E-Sah \& Koh H. C., (2001). Factors Associated With Auditor Changes: A Singapore Study. Accounting and Business Research Vol 31. No. 2: 133144. 